\section{Childhood onset insomnia}

Helga Peter ${ }^{1}$ und Thomas Penzel ${ }^{2}$

${ }^{1}$ Marburg, Deutschland

${ }^{2}$ Interdisziplinäres Schlafmedizinisches Zentrum, Charité -

Universitätsmedizin Berlin, Berlin, Deutschland

\section{Definition}

Insomnie mit Beginn in der Kindheit. Siehe $>$ „Idiopathische Insomnie“. 